\section{Neidealno strujanje u modelnim cijevima}

\author{
F. Kurt, * K. Lichti V. Kosar
}

Fakultet kemijskog inženjerstva i tehnologije, Marulićev trg 19, 10000 Zagreb, Hrvatska
https://doi.org/10.15255/KUI.2020.027

$\mathrm{KUI}-49 / 2020$

Izvorni znanstveni rad

Prispjelo 21. travnja 2020.

Prihvaćeno 16. srpnja 2020.

Ovo djelo je dano na korištenje pod

Creative Commons Attribution 4.0

\title{
Sažetak
}

Cilj ovog rada bio je istražiti strujanje kapljevine u trima različitim modelnim cijevima: ravnoj praznoj cijevi, cijevi ispunjenoj staklenim kuglicama i praznoj spiralnoj cijevi. Pri tome je osnovni koncept sadržan u pojmu raspodjele vremena zadržavanja kapljevine (RVZ). Kako bi se dobile RVZ krivulje, eksperimentalno je mjerena koncentracija inertne tvari (engl. tracer) na izlasku iz cijevi tijekom vremena. Kao inertna tvar upotrijebljena je otopina vodljive soli KCl. Pomoću modela aksijalne disperzije izračunate su vrijednosti srednjeg vremena zadržavanja i disperzijskog broja za različite protoke $\left(100-600 \mathrm{ml} \mathrm{min}^{-1}\right)$ i volumene inertne tvari $(0,3 \mathrm{i} 1 \mathrm{ml})$ te je dan kvantitativan opis odstupanja od idealnog strujanja.

\section{Ključne riječi}

Idealno strujanje, neidealno strujanje, raspodjela vremena zadržavanja, srednje vrijeme zadržavanja, disperzijski broj

\section{Uvod}

\subsection{Raspodjela vremena zadržavanja}

Dva su granična slučaja gibanja/prolaska reakcijske smjese $\mathrm{u} / \mathrm{kroz}$ reaktor: idealno strujanje i idealno miješanje. $U$ realnim sustavima uvijek dolazi do odstupanja od graničnih slučajeva. Kada u realnom sustavu nije moguće predvidjeti ili opisati hidrodinamiku fluida koji struji kroz reaktor, potrebno je odrediti model strujanja koji nam daje podatke o odstupanju od graničnih načina strujanja. Odstupanje od idealnosti moguće je opisati eksperimentalnim određivanjem funkcije raspodjele vremena zadržavanja. ${ }^{1}$

Vjerojatnost s kojom će promatrani element fluida $(\mathrm{d} V)$ izaći iz reaktora nakon određenog vremena izražava se funkcijom raspodjele vremena zadržavanja - RVZ funkcijom. RVZ funkcija je statistička raspodjela, što znači da ukupna vjerojatnost prikazana površinom ispod krivulje na slici 1 mora biti jednaka jedinici, prema jedn. (1). Razlog tomu je što pratimo vjerojatnost da će uneseni diferencijalni volumen izaći iz reaktora, a ta vjerojatnost iznosi $100 \%$. RVZ funkcije se uobičajeno označavaju oznakom $E_{z}$ prema Exit function. ${ }^{2}$

$$
\int_{0}^{\infty} E_{z}(t) d t=1
$$

U slučaju idealnog strujanja svaki element fluida ima istu maksimalnu vjerojatnost da će se u reaktoru zadržati određeno vrijeme koje je jednako za sve elemente. Iz toga slijedi kako u idealnom cijevnom reaktoru ne postoji raspodjela vremena zadržavanja, stoga je u ovom slučaju
RVZ funkcija definirana Diracovom ili delta funkcijom koja je opisana jedn. (4). ${ }^{3,4}$

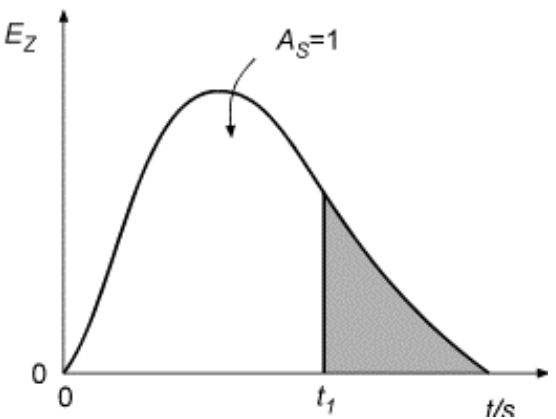

Slika 1 - Funkcija raspodjele vremena zadržavanja za fluid koji protječe kroz reaktor

Fig. 1 - Residence time distribution function for fluid flowing through the reactor

Ako vrijeme ulaska jednog elementarnog volumena u reaktor iznosi 0 , tada slijedi:

$$
\begin{aligned}
& E_{\mathrm{z}}(t)=\delta(t)=0 \quad \text { za } \quad t=0, \\
& E_{\mathrm{z}}(t)=\delta(t)=1 \quad \text { za } \quad t \neq 0 .
\end{aligned}
$$

Iz toga proizlazi definicija delta funkcije:

$$
\int_{-\infty}^{\infty} \delta(t) d t=1
$$

\footnotetext{
*Autor za dopisivanje: Filip Kurt, bacc. ing. ecoing. e-pošta: fkurt@fkit.hr
} 
Poznavanje raspodjele vremena zadržavanja je od velike pomoći u identificiranju neidealnog toka u reaktorima. Točno poznavanje stupnja aksijalnog miješanja važno je za modeliranje i projektiranje reaktora jer ono u konačnici utječe na performanse reaktora $u$ smislu konverzije i prinosa. Ispitivanja raspodjele vremena zadržavanja primjenjuju se i za proučavanje problema u strujanju kao što su recirkulacija, promjena smjera ili stagnacija koji smanjuju učinkovitost procesne jedinice. ${ }^{5,6} \mathrm{O}$ načinu strujanja ovisi i prijenos tvari i topline unutar procesne jedinice, pa je tako u prehrambenoj industriji raspodjela temperature i vremena zadržavanja u cijevima važna za postizanje propisane kvalitete proizvoda. RVZ analize imaju široku primjenu u različitim granama industrije, poput petrokemijske gdje su nužne za optimizaciju destilacijskih kolona. ${ }^{7}$ Nadalje, pomažu u praćenju i izradi modela za predviđanje putanje onečišćujućih tvari u vodama ili zrakom. Takve su analize također bitne pri mikrobiološkoj obradi otpadne vode i za provedbu farmakoloških ispitivanja. ${ }^{4}$

\subsection{Model aksijalne disperzije}

Model aksijalne disperzije primjenjuje se za opis strujanja kroz cijevne reaktore koja malo odstupaju od idealnoga strujanja, a posebno je pogodan za reaktore s nepokretnim slojem katalizatora. $U$ osnovi je tog modela idealno strujanje kojem se pridodaje izvjesno makrostrujanje $u$ smjeru osi, koje se opisuje difuzijskim prijenosom. ${ }^{8}$ Strujanje prema modelu aksijalne disperzije prikazano je na slici 2. Difuzijski je prijenos dan drugim Fickovim zakonom prikazanim jedn. (5), gdje je $D_{e}$ prosječni koeficijent difuzije ili koeficijent disperzije:

$$
\frac{\partial c}{\partial t}=D_{\mathrm{e}} \frac{\partial^{2} C}{\partial z^{2}}
$$

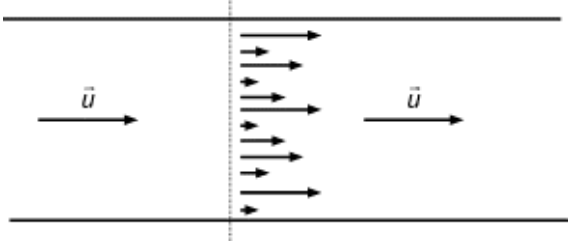

Slika 2 - Strujanje prema modelu aksijalne disperzije

Fig. 2 - Axial dispersion model flow

Realno strujanje može se aproksimirati modelom aksijalne disperzije ukoliko pretpostavimo da je disperzija uzrokovana difuzijom nezavisna o položaju unutar reaktora, da su linearna brzina fluida i koncentracija reaktanata po presjeku reaktora konstantne te da $\mathrm{u}$ reaktoru ne postoje mjesta sa stagnantnim strujanjem i obilascima. ${ }^{8}$
Raspodjela vremena zadržavanja (RVZ krivulja) nalazi se pomoću bilance množine tvari unutar elementa volumena $\Delta V$. Jednostavnim matematičkim postupcima dolazi se do jednadžbe modela aksijalne disperzije za prijenos tvari konvekcijom i difuzijom u nestacionarnom stanju (bilanca za $\Delta V$ ):

$$
\frac{\partial C}{\partial t}=D_{e} \frac{\partial^{2} C}{\partial z^{2}}-u \frac{\partial C}{\partial z}
$$

Uvođenjem novih varijabli bezdimenzijskog vremena (7) i duljine (8) model poprima bezdimenzijski oblik prikazan jedn. (12). ${ }^{2,5}$

$$
\begin{aligned}
& \theta=\frac{t u}{L} \\
& x=\frac{z}{L}
\end{aligned}
$$

Nakon deriviranja:

$$
\partial t=\frac{L}{u} \partial \theta \quad i \quad d z=L d x
$$

i uvrštavanja u jedn. (6), dobije se izraz (10). Sređivanjem izraz poprima oblik jedn. (11) u kojoj omjer $D_{\mathrm{e}} / u L$ predstavlja tzv. bezdimenzijski disperzijski broj (DB).

$$
\begin{gathered}
\frac{\partial C}{\frac{L}{u} \partial \theta}=D_{\mathrm{e}} \frac{\partial^{2} C}{L^{2} d x^{2}}-u \frac{\partial C}{L d x} \\
\frac{\partial C}{\partial \theta}=\frac{D_{\mathrm{e}}}{u L} \frac{\partial^{2} C}{\partial x^{2}}-\frac{\partial C}{\partial x} \\
\frac{\partial C}{\partial \theta}=D B \frac{\partial^{2} C}{\partial x^{2}}-\frac{\partial C}{\partial x}
\end{gathered}
$$

Disperzijski broj $D B$ karakterističan je parametar modela aksijalne disperzije. U slučaju da nema disperzije $D B \rightarrow 0$, i strujanje je idealno. Ako se radi o potpunoj disperziji $D B \rightarrow \infty$, radi se o slučaju idealnog miješanja. U slučaju realnog strujanja disperzijska značajka je između navedenih graničnih vrijednosti. Rješenje jednadžbe modela (6) ovisi o postavljenim rubnim uvjetima na ulazu i izlazu iz sustava. ${ }^{2,5}$

Za mala odstupanja od idealnog strujanja model aksijalne disperzije daje simetričnu raspodjelu, odnosno oblik Gaussove krivulje, pa se $E_{z}$ funkcija može definirati iz izraza: 


$$
E_{z}(\theta)=\frac{1}{2 \sqrt{\pi D B_{1}}} \exp \left[\frac{(1-\theta)^{2}}{4 D B_{1}}\right]
$$

U ovom su slučaju varijanca i disperzijski broj povezani relacijom:

$$
\begin{gathered}
\sigma_{\theta}^{2}=2 D B_{1} \\
D B_{1}=\frac{\sigma_{\theta}^{2}}{2}
\end{gathered}
$$

Uz pretpostavku da na ulazu i izlazu sustava postoji disperzija u strujanju, odnosno da je sustav otvoren, moguće je jednostavno analitičko rješenje jednadžbe za prijenos tvari konvekcijom i difuzijom pa je $E_{z}$ dan izrazom:

$$
E_{z}(\theta)=\frac{1}{2 \sqrt{\pi \theta D B_{2}}} \exp \left[-\frac{(1-\theta)^{2}}{4 \theta D B_{2}}\right]
$$

U slučaju otvorenog sustava disperzijska značajka povezana je s varijancom preko izraza:

$$
\begin{gathered}
\sigma_{\theta}^{2}=2 D B_{2}+8 D B_{2}^{2} \\
D B_{2}=-\frac{1}{8} \pm \frac{\sqrt{4+64 \sigma_{\theta}^{2}}}{16}
\end{gathered}
$$

\section{Eksperimentalni dio}

\subsection{Eksperimentalna metoda određivanja RVZ}

Eksperiment je proveden $\mathrm{u}$ tri modelne cijevi bez prisutnosti kemijske reakcije. Za analizu strujanja primijenjena je metoda impulsnog poremećaja koja se aproksimira Diracovom funkcijom. To znači da je određenu količinu inertne tvari potrebno unijeti u sustav $u$ što kraćem vremenu. Upotreba inertne tvari omogućuje razlikovanje promatranog diferencijalnog volumena od ostatka protoka. Prolazak inertne tvari kroz promatrani sustav očituje se promjenom koncentracije koja je proporcionalna promjeni vodljivosti. Inertna tvar ne smije mijenjati hidrodinamička svojstva ispitivanog fluida (voda), kemijski reagirati s njim te se njegova koncentracija na izlazu mora moći precizno odrediti. Unos inertne tvari u sustav smatra se poremećajem sustava, te se analizom odziva i određivanjem raspodjele vremena zadržavanja može zaključiti o kakvom se strujanju radi. ${ }^{1,4}$

\subsection{Aparatura i postupak mjerenja}

Upotrijebljena aparatura, prikazana na slici 3, sastoji se od ravne prazne cijevi (RC), cijevi ispunjene kuglicama (CK) te duge spiralne cijevi (SC). Duljine ravne prazne cijevi i cijevi ispunjene kuglicama iznose $1 \mathrm{~m}$, a spiralna cijev je dugačka $3 \mathrm{~m}$. Na početku rada zatvara se ventil za ispust vode iz aparature te se otvore ventili na sve tri cijevi da bi se osigurao nesmetan protok vode sustavom. Otvaranjem slavine za dovod vode dolazi do punjenja sustava. Voda prije ulaska u cijev najprije prolazi kroz rotametar, kojim se mjeri željeni protok vode u sustavu. Ispod svake cijevi nalazi se septum kroz koji se injektira inertna tvar. Na vrhu cijevi nalazi se protočna konduktometrijska ćelija sastavljena od Pt-elektroda, kojom se svake sekunde mjeri vodljivost kapljevine, koja se mijenja prolaskom inertne tvari. Za baznu liniju uzima se vrijednost vodljivosti vodovodne vode koja obično iznosi između 0,55 i 0,65 mS te po toj vrijednosti prepoznajemo kada je sva inertna tvar izašla iz sustava. Nastali signal se preko konduktometra vodi na računalo koje pretvara vodljivost u naponski signal, koji se očitava u obliku pika na grafu pomoću računalnog programa NI SignalExpress. Kao inertna tvar upotrijebljena je otopina kalijeva klorida koncentracije $200 \mathrm{gl}^{-1}$. Mjerenja su za svaku cijev provedena tri puta za svaki od ispitivanih protoka: 100, 200, 300, 400, 500 i $600 \mathrm{ml} \mathrm{min}^{-1}$. Eksperiment je napravljen s volumenima inertne tvari od $1 \mathrm{ml} \mathrm{i} 0,3 \mathrm{ml}$.

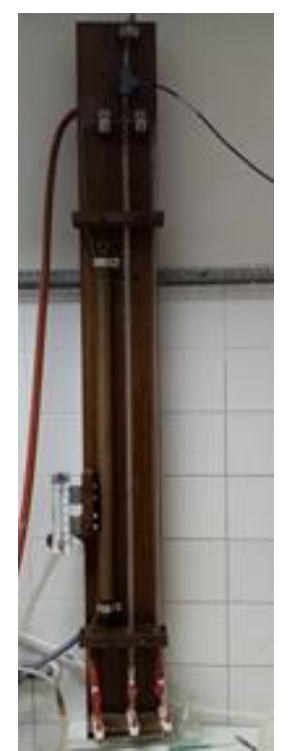

Slika 3 - Eksperimentalna aparatura za određivanje RVZ funkcija Fig. 3 - Experimental apparatus for determining RTD functions

Kao rezultati eksperimenata provedenih u trima cijevima uz različite protoke i volumene inertne tvari dobivene su RVZ krivulje. Slika 4 prikazuje eksperimentalne RVZ krivulje (tzv. C-krivulje) za strujanje u svim trima cijevima pri protoku od $300 \mathrm{ml} \mathrm{min}^{-1}$. 


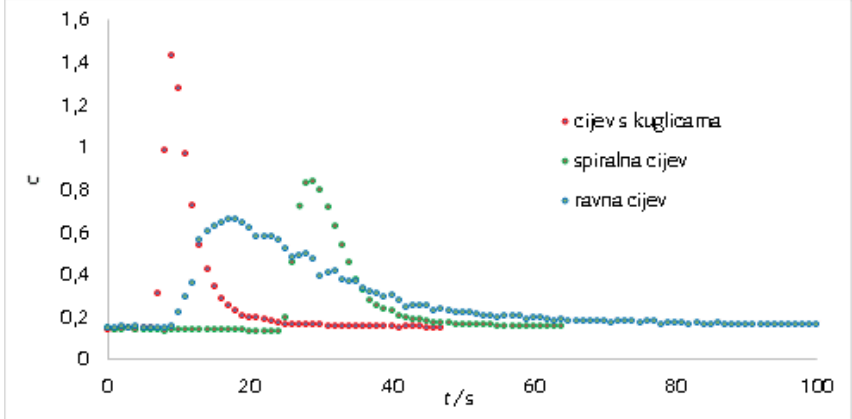

Slika 4 - Raspodjela vremena zadržavanja pri protoku od $300 \mathrm{ml} \mathrm{min}{ }^{-1} \mathrm{i}$ uz volumen inertne tvari $1 \mathrm{ml}$

Fig. 4 - Residence time distribution at a flow rate of $300 \mathrm{ml} \mathrm{min}-1$ and with a tracer volume of $1 \mathrm{ml}$

Eksperimentalno dobiveni rezultati koncentracije inertne tvari $c_{i}$ i vremenskog intervala $\Delta t(1 \mathrm{~s})$ potrebni su za daljnji izračun koji se odvija u sljedećim koracima. ${ }^{2}$

a) Iz eksperimentalno dobivenih vrijednosti koncentracije inertne tvari određuje se najmanja vrijednost $\rightarrow c_{i m i n}$

b) potrebno je od svake koncentracije oduzeti minimalnu koncentraciju da bi početna koncentracija na y-osi bila na nuli:

$$
C_{\text {inorm }}=C_{i}-C_{\text {imin }}
$$

c) zatim se određuje približna površina $Q$ ispod krivulje:

$$
Q=\sum_{i=1}^{n} C_{i n o r m} \Delta t_{i}
$$

d) srednje vrijeme zadržavanja ${ }^{-}$jednako je:

$$
\bar{t}=\frac{\sum_{i=1}^{n} c_{\text {inorm }} t_{i}}{\sum_{i=1}^{n} c_{\text {inorm }}}
$$

e) varijanca $\sigma^{2}$ eksperimentalno određene krivulje je:

$$
\sigma^{2}=\frac{\sum_{i=1}^{n} t_{i}^{2} C_{\text {inorm }}}{\sum_{i=1}^{n} c_{i}}-\overline{t^{2}}
$$

f) bezdimenzijska varijanca, $\sigma_{\theta}^{2}$, je:

$$
\sigma_{\theta}^{2}=\frac{\sigma^{2}}{\overline{t^{2}}}
$$

\section{Rezultati i rasprava}

Kako bi se mogao vizualno pratiti prolaz inertne tvari kroz sustav, proveden je eksperiment s obojenom inertnom tvari. To je omogućilo lakše uočavanje razlika u načinu strujanja u pojedinim cijevima, što je dokaz različitog stupnja miješanja. Slika 5 pokazuje različite profile strujanja u svakoj cijevi. U praznoj ravnoj cijevi primijećeno je uspostavljanje profila brzine karakterističnog za laminarno strujanje, dok u drugoj cijevi dolazi do izravnavanja profila strujanja zbog prisutnosti staklenih kuglica.

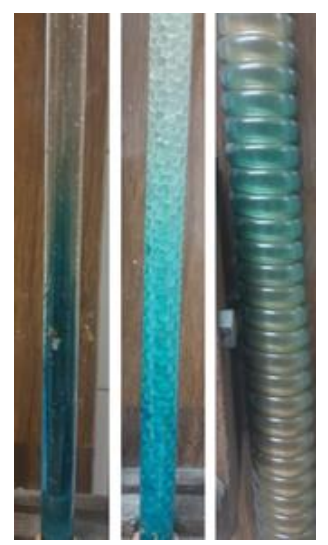

Slika 5 - Prolaz obojene inertne tvari kroz ravnu praznu cijev, cijev s kuglicama i spiralnu cijev

Fig. 5 - Flow of coloured tracer through empty straight tube, tube filled with glass beads, and spiral tube

Na sljedećim slikama prikazane su normalizirane RVZ krivulje u bezdimenzijskom obliku (tzv. $E_{z}$-krivulje), pri čemu su $E_{z}$ i $\theta$ računati prema formulama:

$$
\begin{gathered}
\theta=\frac{t_{i}}{\bar{t}} \\
E_{\mathrm{z}}(\theta)=E_{\mathrm{z}}(t) \bar{t}
\end{gathered}
$$

Utjecaj povećanja protoka na strujanje u svakoj od cijevi prikazan je na slikama 6, 7 i 8. Slika 9 prikazuje normaliziranu bezdimenzijsku krivulju koja odgovara eksperimentalnoj krivulji na slici 4. Bezdimenzijske krivulje daju znatno bolji uvid u provedene eksperimente. Posebno je važno pratiti kako su pikovi pojedinih eksperimenata pozicionirani $u$ odnosu na vrijednost $x$ osi $\theta=1$. Ta vrijednost ukazuje na to da je srednje vrijeme zadržavanja jednako trenutnom vremenu što je tipično za idealno strujanje. Očekivano, povećanjem protoka inertne tvari smanjuje se disperzija u sustavu i pikovi su sve viši i uži.

Iz slike 6 može se uočiti značajno odstupanje od idealnog strujanja u ravnoj praznoj cijevi. Ono je posebno izraženo

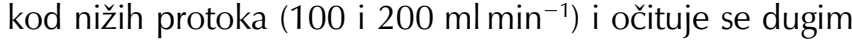
"repom", koji ukazuje na značajnu disperziju u sustavu. U usporedbi s ravnom praznom cijevi u spiralnoj cijevi (slika 7) je strujanje znatno bliže idealnom. Treba uzeti u obzir, s obzirom na duljinu cijevi, da je inertnoj tvari potrebno znatno dulje vrijeme da dođe do konduktometrijske ćelije. Kod eksperimenata u cijevi punjenoj staklenim kuglicama (slika 8) vidi se pravilan utjecaj porasta brzine protoka na približavanje odzivu idealnog strujanja. 


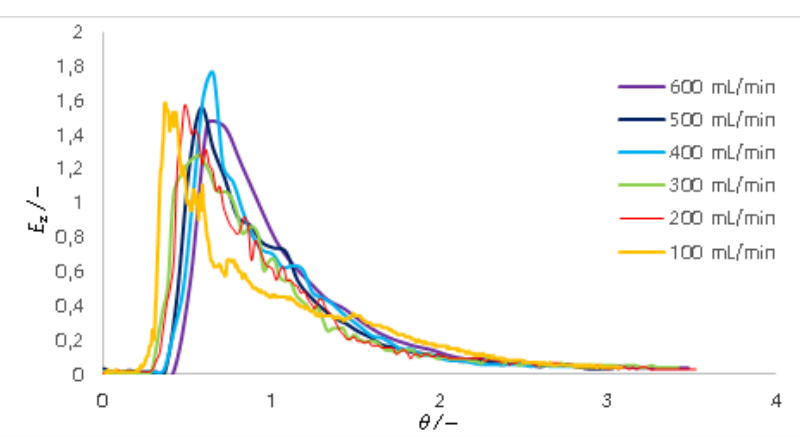

Slika 6 - Utjecaj povećanja protoka na strujanje u ravnoj cijevi Fig. 6 - Influence of flow increase in empty straight tube

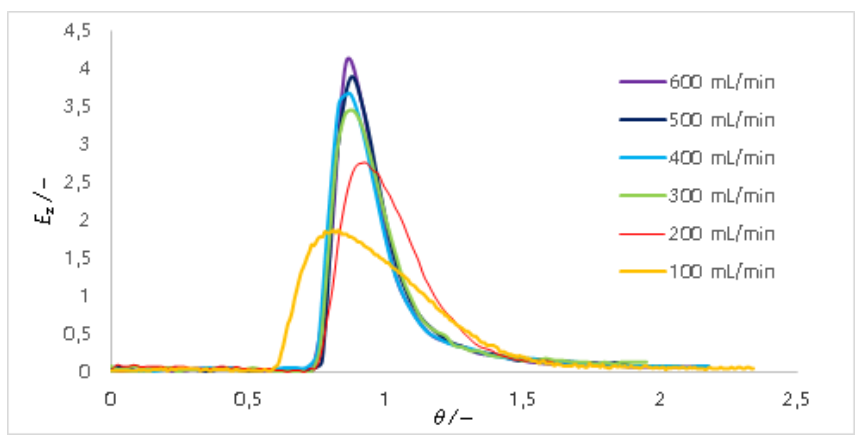

Slika 7 - Utjecaj povećanja protoka na strujanje u spiralnoj cijevi Fig. 7 - Influence of flow increase in spiral tube

Izračunati parametri modela, prikazani u tablicama 1 i 2, pokazuju isti trend vidljiv na krivuljama. Povećanjem protoka smanjuju se disperzijski brojevi i srednje vrijeme zadržavanja, što ukazuje na idealnije strujanje. $U$ ovome radu primijenjene su dvije modifikacije s obzirom na pretpostavljene rubne uvjete modela aksijalne disperzije, zatvoreno-zatvoreno $\left(D B_{1}\right)$ i otvoreno-otvoreno $\left(D B_{2}\right)^{2}$. Pretpostavka otvoreno-otvoreno uzima u obzir određenu disperziju na ulazu i izlazu iz cijevi, što je svakako precizniji opis eksperimentalnog sustava.

Razlike između strujanja u različitim cijevima mogu se objasniti različitom geometrijom. Naime, ravne cijevi imaju isti promjer $\mathrm{i}$ duljinu $(1 \mathrm{~cm} / 1 \mathrm{~m})$, dok je spiralna cijev nešto uža $(0,7 \mathrm{~cm})$ i tri puta dulja $(2,7 \mathrm{~m})$. Veći omjer duljina/radijus pridonosi formiranju idealnog strujanja, na što ukazuju najmanje vrijednosti disperzijskih brojeva za spiralnu cijev. U cijevi s kuglicama je zbog punjenja znatno smanjen slobodan volumen, što utječe na brže strujanje te manje disperzijske brojeve nego u slučaju prazne cijevi. Kuglice ujednačavaju brzine po presjeku cijevi, što također pridonosi idealnijem strujanju. Eksperimenti s manjim volumenom inertne tvari, očekivano, rezultirali su manjim vrijednostima disperzijskog broja i vremena zadržavanja.

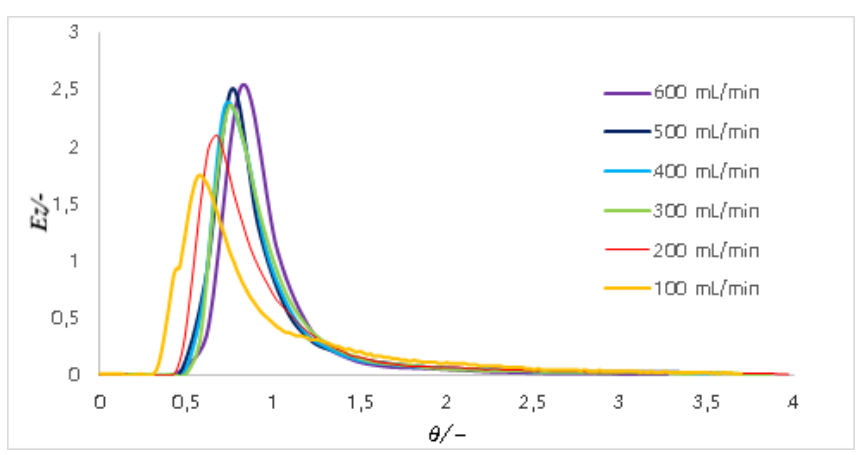

Slika 8 - Utjecaj povećanja protoka na strujanje u cijevi s kuglicama

Fig. 8 - Influence of flow increase in tube with glass beads

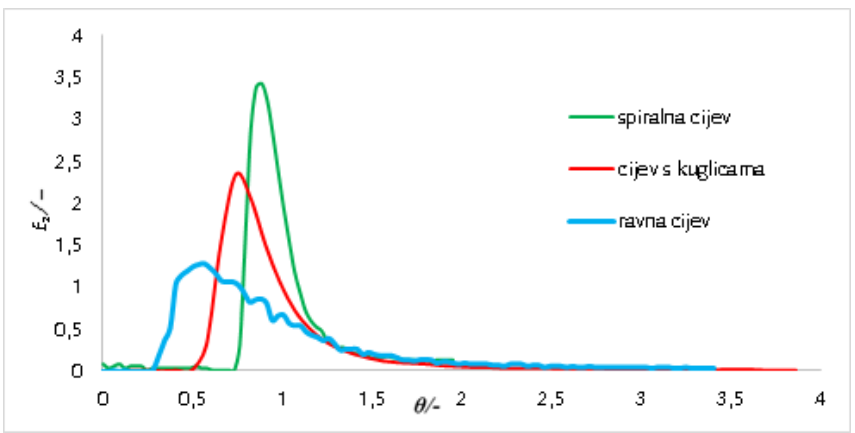

Slika 9 - Strujanje u različitim cijevima pri protoku $300 \mathrm{ml} \mathrm{min}{ }^{-1}$ uz volumen inertne tvari $1 \mathrm{ml}$

Fig. 9 - Flow in different tubes at a flow rate of $300 \mathrm{ml} \mathrm{min}{ }^{-1}$ and with a tracer volume of $1 \mathrm{ml}$

Tablica 1 - Izračunati parametri modela aksijalne disperzije za volumen inertne tvari 0,3 ml

Table 1 - Calculated parameters of axial dispersion model for tracer volume of $0.3 \mathrm{ml}$

\begin{tabular}{|c|c|c|c|c|c|c|c|c|c|}
\hline \multirow{2}{*}{$\begin{array}{l}\text { Protok/ } \\
\mathrm{ml} \mathrm{min}^{-1}\end{array}$} & \multicolumn{3}{|c|}{$\bar{t} / \mathrm{s}$} & \multicolumn{3}{|c|}{$D B_{1}$} & \multicolumn{3}{|c|}{$D B_{2}$} \\
\hline & $\mathrm{RC}$ & CK & $\mathrm{SC}$ & $\mathrm{RC}$ & CK & SC & $\mathrm{RC}$ & CK & SC \\
\hline 100 & 202 & 52 & 155 & 0,269 & 0,116 & 0,088 & 0,163 & 0,086 & 0,069 \\
\hline 200 & 55 & 18 & 55 & 0,249 & 0,106 & 0,066 & 0,154 & 0,124 & 0,054 \\
\hline 300 & 25 & 11 & 33 & 0,221 & 0,098 & 0,027 & 0,141 & 0,081 & 0,024 \\
\hline 400 & 16 & 8 & 25 & 0,192 & 0,083 & 0,038 & 0,127 & 0,070 & 0,034 \\
\hline 500 & 11 & 6 & 18 & 0,111 & 0,075 & 0,026 & 0,083 & 0,060 & 0,023 \\
\hline 600 & 8 & 5 & 15 & 0,100 & 0,061 & 0,010 & 0,077 & 0,051 & 0,010 \\
\hline
\end{tabular}


Tablica 2 - Izračunati parametri modela aksijalne disperzije za volumen inertne tvari $1 \mathrm{ml}$

Table 2 - Calculated parameters of axial dispersion model for tracer volume of $1 \mathrm{ml}$

\begin{tabular}{|c|c|c|c|c|c|c|c|c|c|}
\hline \multirow{2}{*}{$\begin{array}{l}\text { Protok/ } \\
\mathrm{ml} \mathrm{min}^{-1}\end{array}$} & \multicolumn{3}{|c|}{$\bar{t} / \mathrm{s}$} & \multicolumn{3}{|c|}{$D B_{1}$} & \multicolumn{3}{|c|}{$D B_{2}$} \\
\hline & $\mathrm{RC}$ & CK & SC & $\mathrm{RC}$ & CK & SC & $\mathrm{RC}$ & CK & SC \\
\hline 100 & 172 & 60 & 124 & 0,195 & 0,178 & 0,036 & 0,129 & 0,112 & 0,036 \\
\hline 200 & 46 & 20 & 50 & 0,179 & 0,157 & 0,031 & 0,120 & 0,109 & 0,026 \\
\hline 300 & 29 & 12 & 33 & 0,190 & 0,126 & 0,029 & 0,126 & 0,081 & 0,029 \\
\hline 400 & 18 & 8 & 25 & 0,121 & 0,116 & 0,029 & 0,089 & 0,086 & 0,026 \\
\hline 500 & 14 & 6 & 19 & 0,120 & 0,104 & 0,028 & 0,106 & 0,078 & 0,025 \\
\hline 600 & 11 & 5 & 16 & 0,119 & 0,097 & 0,025 & 0,087 & 0,074 & 0,025 \\
\hline
\end{tabular}

\section{Zaključak}

Usporedbom provedenih eksperimenata s modelom aksijalne disperzije te izračunavanjem njegovih parametara, disperzijskog broja te srednjeg vremena zadržavanja doneseni su sljedeći zaključci:

- Najdulje vrijeme zadržavanja je u ravnoj praznoj cijevi, a najkraće u cijevi ispunjenoj staklenim kuglicama.

- Vrijednosti disperzijskog broja najmanje su za dugu spiralnu cijev (tablica 1, DB $1=0,01$ pri protoku $600 \mathrm{ml} \mathrm{min}^{-1}$ ).

- U ravnoj praznoj cijevi najviše je izražena disperzija u sustavu (tablica 1, DB $1=0,269$ pri protoku $100 \mathrm{ml} \mathrm{min}^{-1}$ ).

- Eksperimenti s manjim volumenom inertne tvari omogućuju približavanje idealnom ulaznom impulsnom poremećaju s obzirom na kraće vrijeme potrebno za njegov unos.

- Model aksijalne disperzije dobro opisuje promatrani sustav s obzirom na izračunate vrijednosti disperzijskog broja i srednjeg vremena zadržavanja.

\section{Popis kratica i simbola List of abbreviations and symbols}

C - koncentracija, mol dm ${ }^{-3}$

$D_{\mathrm{e}} \quad-$ prosječna (efektivna) difuznost u osnom smjeru, $\mathrm{m}^{2} \mathrm{~s}^{-1}$

$D B \quad$ - značajka disperzije , -

$E_{z} \quad$ - funkcija vremena zadržavanja, razne jedinice

$E(\theta) \quad$ - funkcija vremena zadržavanja u bezdimenzijskom obliku

L $\quad$ - duljina reaktora, $\mathrm{m}$

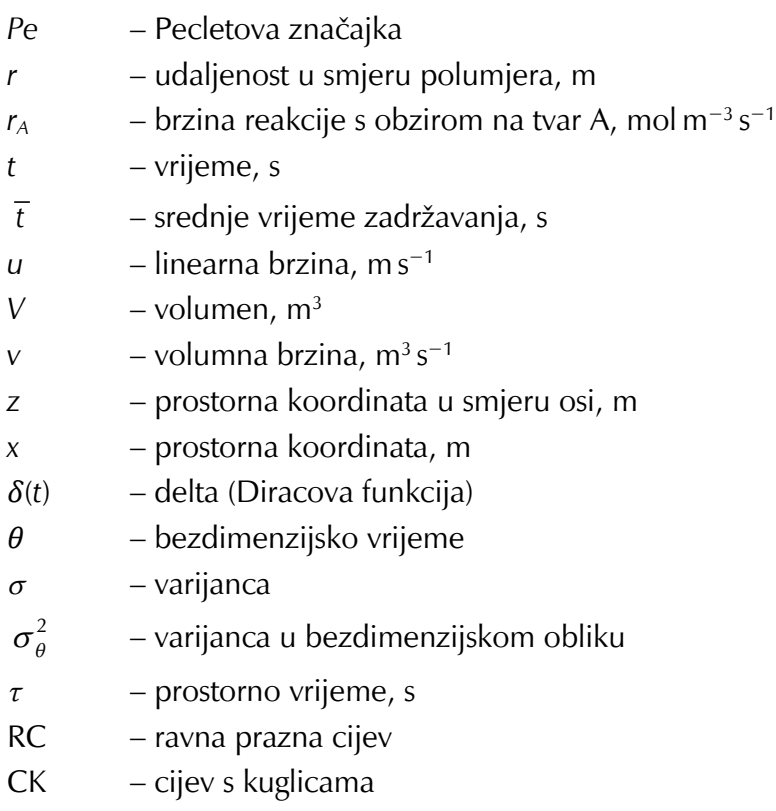

\section{Literatura}

References

1. O. Levenspiel, Chemical Reaction Engineering, $2^{\text {nd }}$ Ed., J. Wiley, New York, 1972., str. 250-355.

2. Z. Gomzi, Kemijski reaktori, Hinus, Zagreb, 1998. str. 281321.

3. P. V. Danckwerts, Continuous flow systems. Distribution of residence times, Chem Eng. Sci. 2 (1953) 1-13, doi: https://doi.org/10.1016/0009-2509(53)80001-1.

4. T. Gottschalk, H. Dehling, Danckwerts' law for mean residence time revisited, Chem. Eng. Sci. 61 (2006) 62136217, doi: https://doi.org/10.1016/j.ces.2006.05.022.

5. M. Sebastian Escotet-Espinoza, S. Moghtadernejad, S. Oka, Z. Wang, Y. Wang, A. Roman-Ospino, M. lerapetritou, Effect of material properties on the residence time distribution (RTD) characterization of powder blending unit operations. Part II of II: Application of models, Ptec 344 (2019) 525-544, doi: https://doi.org/10.1016/j.powtec.2018.12.051. 
6. O. Benhabiles, N. Chekir, W. Taane, Determining the Residence Time Distribution in CPC Reactor Type, Energy Procedia 18 (2012) 368-376, doi: https://doi.org/10.1016/j.egypro.2012.05.048.

7. K. El Korchi, R. Alami, A. Saadaoui, S. Mimount, A. Chaouch, Residence time distribution studies using radiotracers in a lab-scale distillation column: Experiments and modeling. Applied Radiation and Isotopes 154 (2019) 108889, doi: https://doi.org/10.1016/j.apradiso.2019.108889.
8. R. Fazli-Abukheyli, P. Darvishi, Combination of axial dispersion and velocity profile in parallel tanks-in-series compartment model for prediction of residence time distribution in a wide range of non-ideal laminar flow regimes, Chem. Eng. Sci. 195 (2019) 531-540, doi: https://doi.org/10.1016/j.ces.2018.09.052.

\section{SUMMARY}

\section{Non-ideal Flow in Model Tubes}

\section{Filip Kurt, Katarina Licht, and Vanja Kosar}

The aim of this paper was to investigate the flow of liquid in three different model tubes: an empty straight tube, a tube filled with glass beads, and an empty spiral tube. In doing so, the basic concept is contained in the notion of residence time distribution (RTD). In order to obtain RTD curves, the tracer concentration at the exit of the tube was experimentally measured over time. The KCl conductive salt solution was used as the tracer. Using the axial dispersion model, the mean retention time and dispersion number values were calculated for different flows $\left(100-600 \mathrm{ml} \mathrm{min}{ }^{-1}\right)$ and volumes of tracer $(0.3$ and $1 \mathrm{ml})$, and a quantitative description of deviations from the ideal plug flow was given.

\section{Keywords}

Plug flow, non-ideal flow, residence time distribution, mean residence time, dispersion number 